\title{
Efficient and regioselective synthesis of dihydroxy- substituted 2-aminocyclooctane-1-carboxylic acid and its bicyclic derivatives
}

\author{
İlknur Polat ${ }^{1}$, Selçuk Eşsiz ${ }^{1,2}$, Uğur Bozkaya ${ }^{3}$ and Emine Salamci ${ }^{* 1}$
}

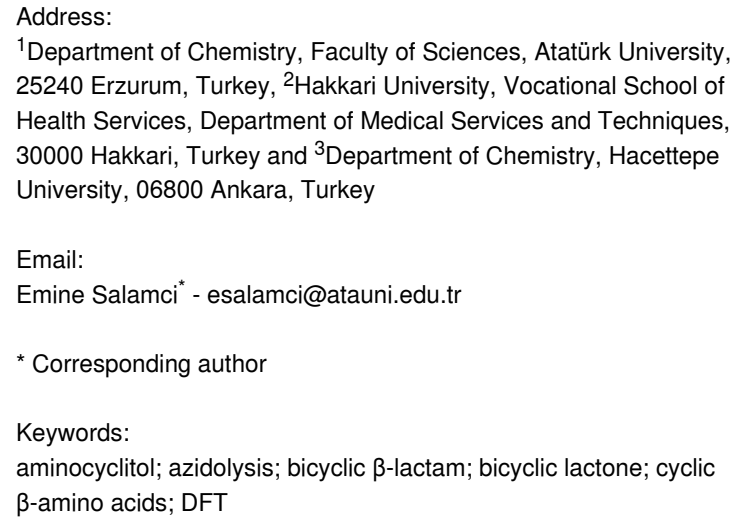

Beilstein J. Org. Chem. 2022, 18, 77-85.

https://doi.org/10.3762/bjoc.18.7

Received: 23 September 2021

Accepted: 22 December 2021

Published: 06 January 2022

Associate Editor: S. Bräse

(C) 2022 Polat et al.; licensee Beilstein-Institut. License and terms: see end of document.

\begin{abstract}
The first synthesis of 2-amino-3,4-dihydroxycyclooctane-1-carboxylic acid, methyl 6-hydroxy-9-oxo-8-oxabicyclo[5.2.1]decan-10yl)carbamate, and 10-amino-6-hydroxy-8-oxabicyclo[5.2.1]decan-9-one starting from cis-9-azabicyclo[6.2.0]dec-6-en-10-one is described. cis-9-Azabicyclo[6.2.0]dec-6-en-10-one was transformed into the corresponding amino ester and its protected amine. Oxidation of the double bond in the $\mathrm{N}$-Boc-protected methyl 2-aminocyclooct-3-ene-1-carboxylate then delivered the targeted amino acid and its derivatives. Density-functional theory (DFT) computations were used to explain the reaction mechanism for the ring opening of the epoxide and the formation of five-membered lactones. The stereochemistry of the synthesized compounds was determined by 1D and 2D NMR spectroscopy. The configuration of methyl 6-hydroxy-9-oxo-8-oxabicyclo[5.2.1]decan-10-yl)carbamate was confirmed by X-ray diffraction.
\end{abstract}

\section{Introduction}

Cyclic $\beta$-amino acids have for the past few decades aroused widespread synthetic interest owing to their diverse biological activities, especially applications in the field of medicinal chemistry. $\beta$-Amino acids (i.e., amino acids containing an extra methylene group in the backbone) occur naturally in peptidic structures [1-5] and have been used in peptide design to obtain mixed peptides that retain their biological activities $[6,7]$.
Moreover, they can be used as starting substances for different heterocycles, as precursors for the synthesis of polymers, as potential pharmacons, for the synthesis of natural products or analogues, and also as building blocks in drug research [8-11]. Furthermore, some $\beta$-amino acid derivatives have antibiotic (oryzoxymycin) and antifungal activities (Figure 1) $[12,13]$. 


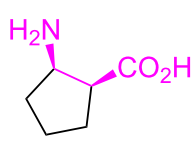

cispentacin

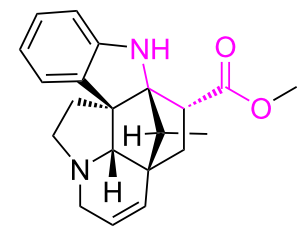

vindolinine<smiles>CC(OC(=O)C1=CC=CC(O)C1N)C(=O)O</smiles>

oryzoxymycin

Figure 1: Examples of natural products containing $\beta$-amino acids.

Among the cyclic $\beta$-amino acids, the most widely investigated derivatives are the five- and six-membered derivatives $[8-10,14,15]$, but only a few synthetic methods are available for the synthesis of $\beta$-amino acids containing seven- [14-16], and eight- $[14,17,18]$ membered rings. Only one of these studies previously reported by Fülöp and co-workers was on the synthesis of hydroxylated cyclooctane amino acids starting from 1,5-cyclooctadiene [17], the others were on the synthesis of non-hydroxylated cyclooctane amino acids $[14,18]$. Also in other ring systems, only non-hydroxylated cyclic amino acids and derivatives were synthesized $[8-10,15,16]$. Therefore, we were inspired to develop new methods for the synthesis of hydroxylated $\beta$-amino acid derivatives containing eight-membered rings. We have recently reported the synthesis of various eight-membered aminocyclitols and their derivatives [19-25]. In the present paper, we describe the synthesis of some hydroxyl- ated $\beta$-amino acid derivatives containing eight-membered rings starting from cis,cis-1,3-cyclooctadiene.

\section{Results and Discussion}

Initially, we focused on the synthesis of $\beta$-lactam 2 , which was prepared by the cycloaddition of chlorosulfonyl isocyanate (CSI) to cis,cis-1,3-cyclooctadiene, as described in the literature [26]. $\beta$-Lactam 2 was transformed into cis-amino ester $\mathbf{3}$ by cleavage of the lactam ring with $\mathrm{HCl}(\mathrm{g})$ in $\mathrm{MeOH}$ (Scheme 1).

$\mathrm{N}$-Boc protection of $\mathrm{cis}$-amino ester 3 with (Boc) ${ }_{2} \mathrm{O}$ in pyridine and 4-(dimethylamino)pyridine (DMAP) gave $\mathrm{N}$-Boc-amino ester 4 (yield 95\%). The ${ }^{1} \mathrm{H}$ and ${ }^{13} \mathrm{C}$ NMR spectroscopic data of 4 were in agreement with the proposed structure. Treatment of 4 with $\mathrm{OsO}_{4} / \mathrm{NMO}$ gave the expected diol $\mathbf{5}$ as a single isomer in $91 \%$ yield. We assume that the trans selectivity of hydroxyl-<smiles>C1=CCCCC=CC1</smiles>

1

\section{1) $\mathrm{CSI}$ \\ 2) $\mathrm{Na}_{2} \mathrm{SO}_{3}, \mathrm{KOH}$} $\mathrm{CH}_{2} \mathrm{Cl}_{2}, 0^{\circ} \mathrm{C}$<smiles>O=C1NC2/C=C\CCCCC12</smiles>

2<smiles>COC(=O)C1CCCCC=CC1NC1CCCCC(C(=O)OC(C)(C)C)C1</smiles>

$\mathrm{OsO}_{4} / \mathrm{NMO}$

$91 \%$<smiles>COC(=O)N[C@H]1C(C(=O)OC(C)(C)C)=CCCC[C@H](O)[C@H]1O</smiles>

5

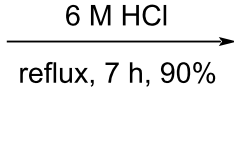

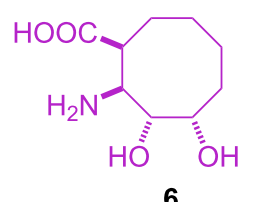

6 
ation in ester $\mathbf{4}$ is due to the steric effect of the presence of the bulky Boc group. The structure of $\mathbf{5}$ was determined with the help of $1 \mathrm{D}\left({ }^{1} \mathrm{H}\right.$ and $\left.{ }^{13} \mathrm{C}\right)$ and 2D (COSY and HMQC) NMR spectra. The diagonal peak at $4.10 \mathrm{ppm}$ has cross peaks with the protons resonating at 2.96, 3.95, and $5.39 \mathrm{ppm}$, respectively, in the COSY spectrum. The cross peak between $\mathrm{H}-2$ and $\mathrm{H}-3 / \mathrm{H}-4$ suggests that the proton $\mathrm{H}-2$ should have a trans configuration relative to the proton $\mathrm{H}-3$. Removal of the Boc protection by $\mathrm{HCl}$ resulted in the formation of the target $\beta$-amino acid $\mathbf{6}$, which was characterized based on its NMR spectra (Scheme 1).

The $N$-Boc-amino ester 4 was reacted with $m$-CPBA to give epoxide 7 as the sole product in $94 \%$ yield (Scheme 2). The structure of 7 was assigned based on its NMR spectra. Epoxide 7 was used as the precursor material in the synthesis of the other isomer of $\beta$-amino acid $\mathbf{6}$. The ring-opening reaction of 7 with $\mathrm{HCl}(\mathrm{g})$ in $\mathrm{MeOH}$ resulted in a mixture of products 8 and 9 in a 9:1 ratio $\left({ }^{1} \mathrm{H}\right.$ NMR). The product 8 in the reaction mixture was purified by recrystallization from ethanol/ether, but all attempts to purify the expected product 9 failed. The product 8 was obtained as the major product in $80 \%$ yield, and the expected product 9 was formed as the minor product in $4 \%$ yield. We propose that diol isomer mixture $\mathbf{9}$ can be formed by solvolysis. The presence of the lactone ring in $\mathbf{8}$ was determined by
2D NMR spectroscopic data (COSY and HMQC). The diagonal peak at $4.62 \mathrm{ppm}$ has cross peaks with the protons resonating at 4.26 and $4.39 \mathrm{ppm}$, respectively, in the COSY spectra of 8 . The cross peak between H-7 and H-6 showed strong correlation, which clearly supports the trans relation of the proton H-6. The cross peak between $\mathrm{H}-7$ and $\mathrm{H}-10$ also showed weak correlation, which clearly supports the cis relation of the proton $\mathrm{H}-10$. In this reaction, lactonization and hydrolysis of the Boc group to the corresponding amine were observed. The formation of lactone $\mathbf{8}$ as the major product can be explained by nucleophilic attack of the neighbouring carboxyl group, which was formed by hydrolysis of the corresponding methyl ester.

For the synthesis of other isomeric $\beta$-amino acid derivatives, epoxide 7 was treated with two equivalent amounts of $\mathrm{NaHSO}_{4}$ [27] in methylene chloride/ $\mathrm{MeOH}$ at room temperature (Scheme 3). The formation of a mixture of products $\mathbf{1 0}$ and $\mathbf{1 1}$ in a 7:3 ratio was determined by NMR spectroscopy. The reaction mixture was purified using preparative silica gel TLC on a chromatotron with ethyl acetate/hexane (50:50) as the eluent to give carbamate $\mathbf{1 0}$ and diol isomer mixture $\mathbf{1 1}$ in $65 \%$ and $25 \%$ yields, respectively. However, all attempts to isolate isomer mixture 11 failed. Again, we suggest that diol isomer mixture
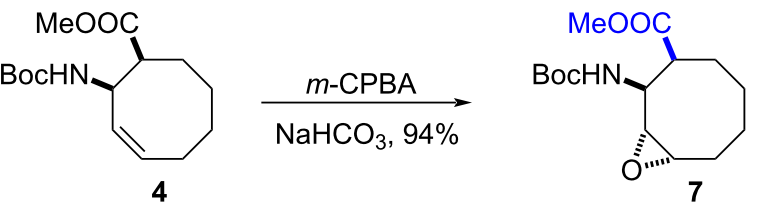

$\mathrm{HCl}(\mathrm{g})-\mathrm{MeOH}$
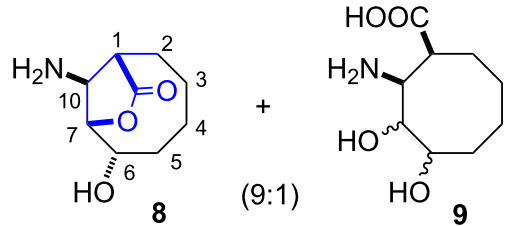

Scheme 2: Epoxidation of Boc-protected amino ester $\mathbf{4}$ and hydrolysis of epoxide $\mathbf{7}$ with $\mathrm{HCl}(\mathrm{g})-\mathrm{MeOH}$.<smiles>[Z]C1O[C@H]1CCCCC(NC(=O)OC(C)(C)C)C(C)=O</smiles>

7

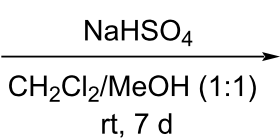

rt, $7 \mathrm{~d}$

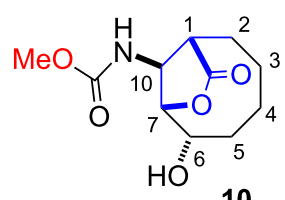

10

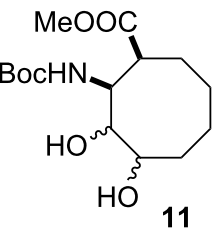


11 can be formed by solvolysis. The presence of the lactone ring in $\mathbf{1 0}$ was determined by 2D NMR spectroscopic data (COSY and HMQC). The diagonal peak at $4.19 \mathrm{ppm}$ has cross peaks with the protons resonating at $4.49,1.53$, and $2.02 \mathrm{ppm}$, respectively, in the COSY spectra of $\mathbf{1 0}$. The cross peak ( $\delta 4.49 \mathrm{ppm}$ ) between H-6 and H-7 showed a strong correlation, which clearly supports the trans relation of the proton H-7. Furthermore, its structure was unambiguously confirmed by single crystal X-ray analysis (Figure 2) [28]. The formation of lactone 10 can again be explained by participation of the neighbouring group, as discussed above. However, during the purification on silica gel of the lactone-Boc product, its transesterification also resulted in corresponding methyl carbamate $\mathbf{1 0}$.
We then investigated the epoxide-ring-opening reaction of 7 with sodium azide, to introduce an extra amino group in position 4 on the cyclooctane skeleton. For this, epoxide 7 was treated with $\mathrm{NaN}_{3}$ in the presence of $\mathrm{NH}_{4} \mathrm{Cl} / \mathrm{DMF}$ and this formed lactone $\mathbf{1 3}$ as the sole product in $80 \%$ yield (Scheme 4 ). The epoxide 7 was treated with $\mathrm{NaN}_{3}$ and $\mathrm{NH}_{4} \mathrm{Cl} / \mathrm{DMF}$ to obtain compound 12. From this reaction, the formation of unexpected lactone $\mathbf{1 3}$ was observed. The reaction was repeated again with only $\mathrm{NH}_{4} \mathrm{Cl}$ and DMF, and the reaction resulted in formation of compound 13. This experiment shows that $\mathrm{NaN}_{3} /$ DMF does not to play any role in this transformation. The structure of 13 was elucidated with the help of the 2D NMR (COSY and HMQC) experiments. Finally, removal of the Boc group

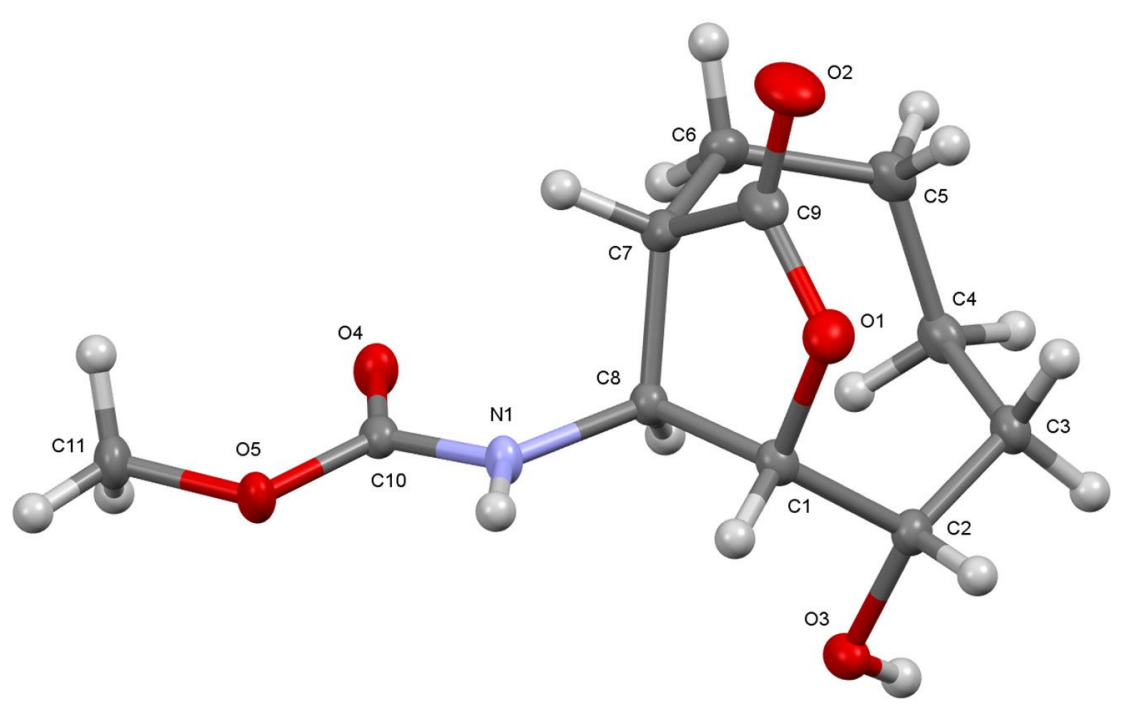

Figure 2: The X-ray crystal structure of $\mathbf{1 0}$

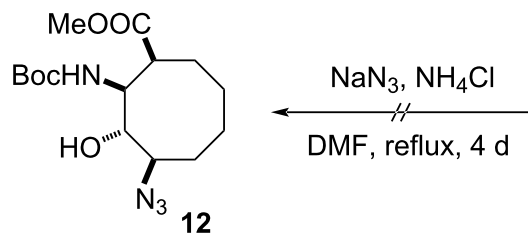<smiles>CC(=O)OC(C)(C)OC(=O)C1CCCCC2OC21</smiles>

7

$\mathrm{NaN}_{3}, \mathrm{NH}_{4} \mathrm{Cl}$

$\mathrm{EtOH} / \mathrm{H}_{2} \mathrm{O}$

reflux, $7 \mathrm{~d}$

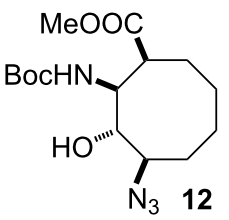

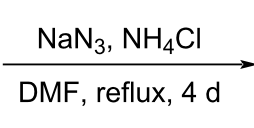

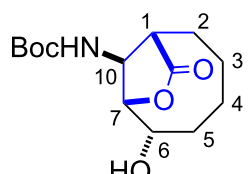

13 $\mathrm{HCl}(\mathrm{g})-\mathrm{MeOH}$

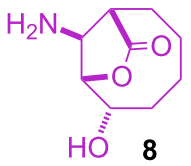


from 13 with $\mathrm{HCl}(\mathrm{g})-\mathrm{MeOH}$ resulted in the formation of cyclic $\beta$-amino acid derivative $\mathbf{8}$ in high yield.

Our suggested mechanism for the reaction of epoxide 7 with $\mathrm{NaHSO}_{4}$ in a mixture of methylene chloride/MeOH proceeded as described in Scheme 5. First, the $\mathrm{C}=\mathrm{O}$ group of the ester prefers to attack the protonated epoxide to give intermediate 15 . Then, water, which is available in methanol as an impurity, attacks the oxonium ion to give dealkylation product 10, which is a typical transesterification reaction.

To explain the formation of lactone 10, we performed a series of DFT computations using the Gaussian 16 software [29]. For this purpose, we performed geometry optimizations using the
B3LYP functional [30-33]. Vibrational frequencies were computed to characterize each stationary structure. In all the computations, Pople's polarized triple- $\zeta$ split valence basis set with diffuse functions, 6-311++G(d,p) [34-36], was utilized. The solvation model based on density (SMD) [37] was used to investigate the effects of methanol $(\varepsilon=32.613)$ and dichloromethane $(\varepsilon=8.93)$ on the computed Gibbs energies. For the TS between species A and B, the TSA-B notation is used throughout the article.

According to the given mechanism in Scheme 5, there are two possible paths for the attack of the carboxyl group on the epoxide ring. For the formation of the five-membered lactone $\mathbf{1 5}$ (path a), $\mathbf{1 4} \rightarrow \mathbf{1 5}$, the reaction proceeds via a barrierless<smiles>CC(=O)C1CCCC[C@@H]2O[C@H]2C1NC(=O)OC(C)(C)C</smiles>

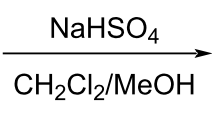

7

$\mathrm{NaHSO}_{4}$ $\mathrm{CH}_{2} \mathrm{Cl}_{2} / \mathrm{MeOH}$

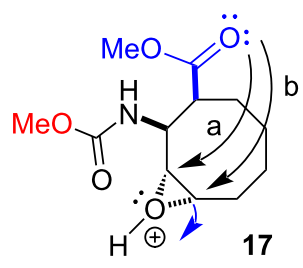<smiles>[C]1CCCC1</smiles><smiles></smiles>

16

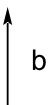

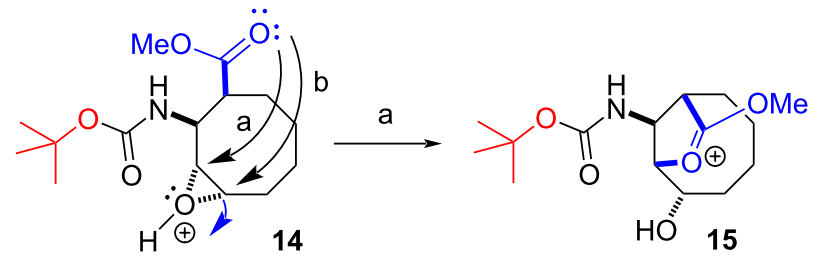

14

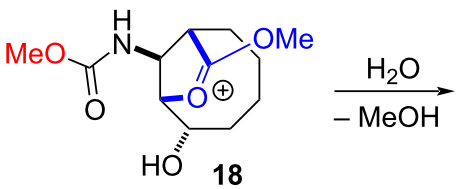<smiles>COC(=O)NC1C2CCCCC(O)C1OC2=O</smiles><smiles>COC(=O)NC1OC(=O)C2C3CCCC(C3)CC12</smiles><smiles>COCCO</smiles>
$-\mathrm{MeOH}$<smiles>COC(=O)NC1C2CCCCC(O2)C(O)C1O</smiles>

not observed 
path and the solvent corrected reaction free energies are -17.5 and $-18.1 \mathrm{kcal} \mathrm{mol}^{-1}$ with methanol and dichloromethane, respectively. For the formation of the six-membered lactone $\mathbf{1 6}$ (path b), $\mathbf{1 4} \rightarrow \mathbf{1 6}$, the solvent corrected reaction free energy and barrier are -9.5 and $14.5 \mathrm{kcal} \mathrm{mol}^{-1}$ with methanol, respectively and -11.1 and $13.5 \mathrm{kcal} \mathrm{mol}^{-1}$ with dichloromethane, respectively (Figure 3). For the formation of the five-membered lactone $\mathbf{1 8}$ (path a), $\mathbf{1 7} \rightarrow \mathbf{1 8}$, the reaction proceeds via a barrierless path and the solvent corrected reaction free energies are -17.2 and $-18.0 \mathrm{kcal} \mathrm{mol}^{-1}$ with methanol and dichloromethane, respectively. For the formation of the six-membered lactone $\mathbf{1 9}$ (path b), $\mathbf{1 7} \rightarrow \mathbf{1 9}$, the solvent corrected reaction free energy and barrier are -5.4 and $14.5 \mathrm{kcal} \mathrm{mol}^{-1}$ in methanol, respectively and -7.1 and $13.4 \mathrm{kcal} \mathrm{mol}^{-1}$ in dichloromethane, respectively (Figure 4). These results indicate that the formation of the methyl carbamate may occur before or after the attack by the carboxyl group. Overall, our computations demonstrate that the $\mathbf{1 4} \rightarrow \mathbf{1 5}$ and $\mathbf{1 7} \rightarrow \mathbf{1 8}$ conversions are kinetically more favourable, by about $14.0 \mathrm{kcal} \mathrm{mol}^{-1}$, compared to the $\mathbf{1 4} \rightarrow \mathbf{1 6}$ and $\mathbf{1 7} \rightarrow \mathbf{1 9}$ conversions. These results rule out the formations of $\mathbf{1 6}$ and $\mathbf{1 9}$ at room temperature. Therefore, we conclude that the final product is lactone $\mathbf{1 0}$, and the formation of lactone $\mathbf{2 0}$ is not feasible under the experimental conditions. Furthermore, lactone $\mathbf{1 0}$ is energetically more stable, by $5.0 \mathrm{kcal} \mathrm{mol}^{-1}$ in methanol and by $3.7 \mathrm{kcal} \mathrm{mol}^{-1}$ in dichloromethane, than lactone 20. The computations were in good agreement with the experimental results (Figure 3 and Figure 4).

To explain why lactone $\mathbf{1 0}$ is formed, a conformational analysis for the epoxide 7 was performed. It is seen that the conformation is quite appropriate for the formation of lactone 10. The hydrogen bond between the $\mathrm{C}=\mathrm{O}$ group of methoxy ester and $\mathrm{NH}$ group of the carbamate in $\mathbf{7}$ provides an appropriate conformation for the formation of lactone 10. Additionally, according to the conformational analysis of epoxide 7 , the relative free energy of $\mathbf{7 b}$ is higher by $10.3 \mathrm{kcal} \mathrm{mol}^{-1}$ than that of $\mathbf{7 a}$ (Figure 5).

\section{Conclusion}

In summary, we successfully synthesized hydroxylated cyclooctane $\beta$-amino acid $\mathbf{6}$ and its derivatives $8, \mathbf{1 0}$, and $\mathbf{1 3}$ starting from $\beta$-lactam 2 . The regioselective synthesis of lactone $\mathbf{8}$, which is a cyclic $\beta$-amino acid derivative, was achieved by oxirane ring opening in epoxide 7 with $\mathrm{HCl}(\mathrm{g})-\mathrm{MeOH}$, $\mathrm{NaHSO}_{4}$, or $\mathrm{NH}_{4} \mathrm{Cl}-\mathrm{DMF}$. The regioselectivity of oxirane ringopening in 7 was attributed to the conformational effects. The mechanism for the formation of compound $\mathbf{1 0}$ was elucidated with DFT computations. Our computations demonstrate that the

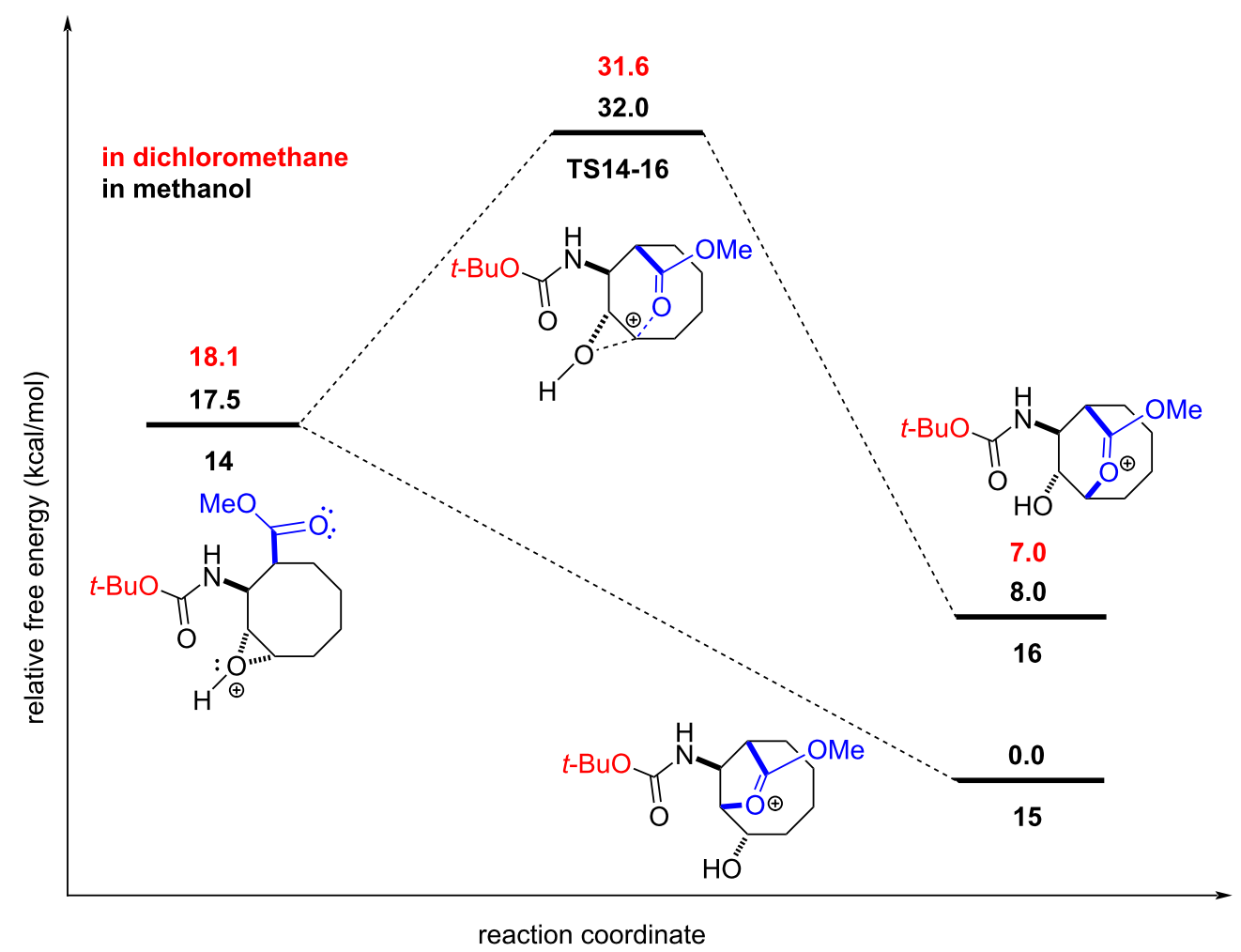

Figure 3: Solvent-corrected relative free energy profile at $298.15 \mathrm{~K}$ for the reaction mechanism of $\mathbf{1 4}$ shown in Scheme 5. 


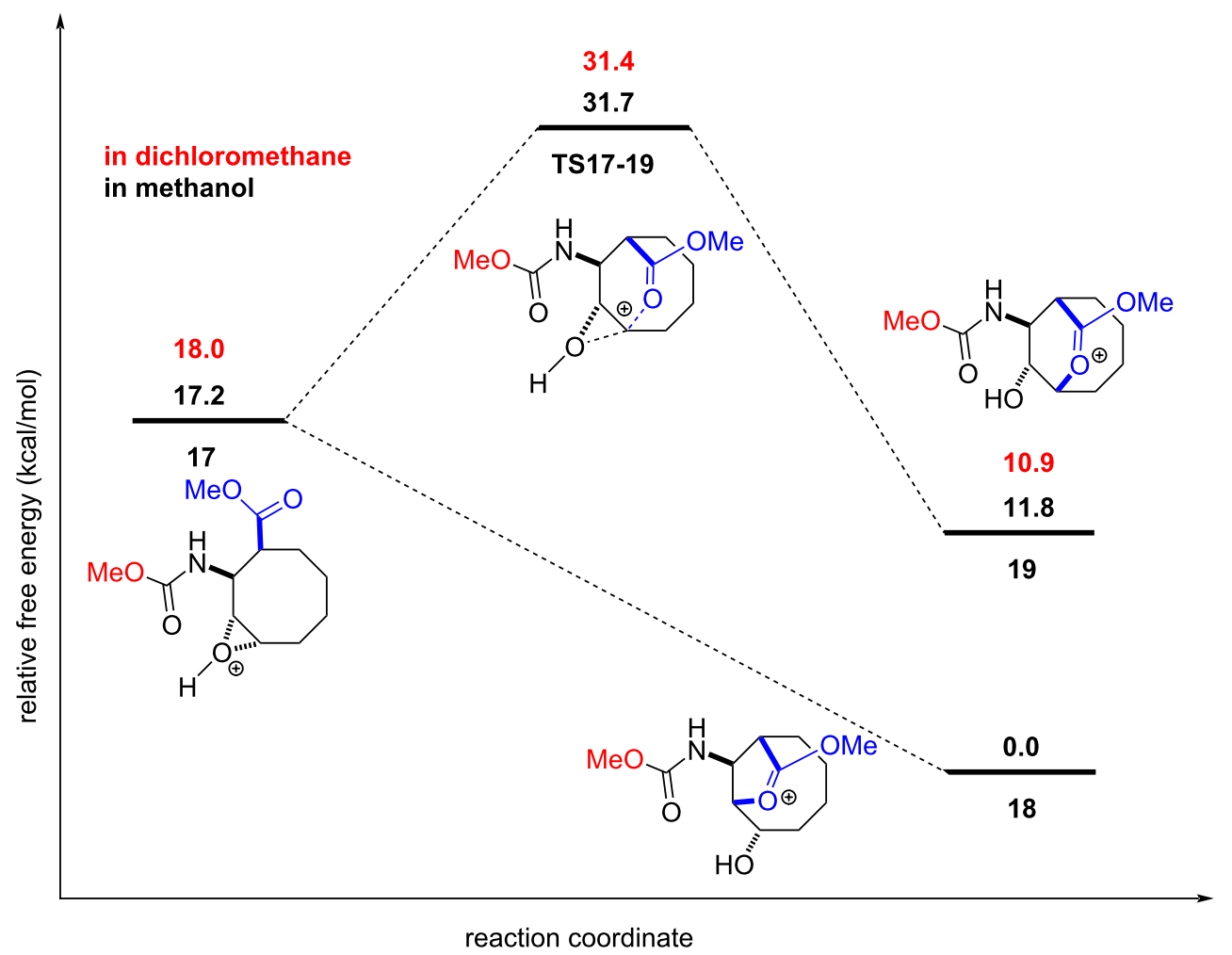

Figure 4: Solvent-corrected relative free energy profile at $298.15 \mathrm{~K}$ for the reaction mechanism of 17 shown in Scheme 5.

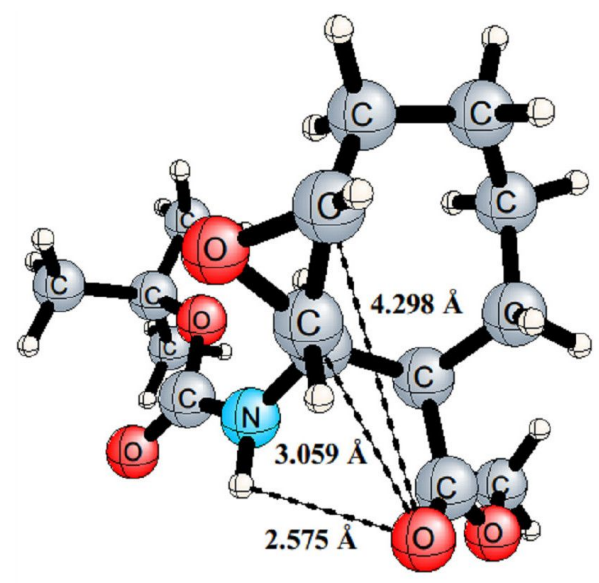

$7 \mathbf{a}$

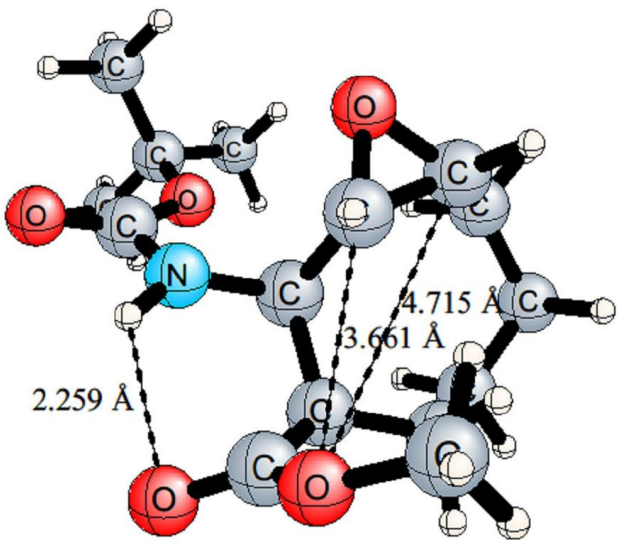

$7 \mathbf{b}$

Figure 5: The optimized geometries of the conformers $7 \mathbf{a}$ and $7 \mathbf{b}$ with selected interatomic distances at the B3LYP/6-311++G(d,p) level.

formation of the five-membered lactone is kinetically more favourable, and the formation of six-membered lactone is not feasible under the experimental conditions. The conformation of epoxide 7 is quite appropriate for the formation of the five- membered lactone 10, in contrast to the formation of the sixmembered lactone 20. In addition, these novel compounds synthesized may be used as intermediates to design pharmacological tools. 


\section{Supporting Information}

Experimental section, ${ }^{1} \mathrm{H}$ and ${ }^{13} \mathrm{C}$ NMR spectra for all new compounds, as well as selected 2D NMR spectra and crystallographic data for compound $\mathbf{1 0}$ are provided. Optimized geometries of the transition states with selected interatomic distances and cartesian coordinates for computed structures are reported.

\section{Supporting Information File 1}

Additional experimental and computed data. [https://www.beilstein-journals.org/bjoc/content/ supplementary/1860-5397-18-7-S1.pdf]

\section{Acknowledgements}

The authors are indebted to the Atatürk University for its support. We would also like to thank Professor Ertan Sahin for performing the X-ray analysis.

\section{Funding}

This study was funded by the Research Fund of the Atatürk University (project number: 2014/54).

\section{ORCID ${ }^{\circledR}$ iDs}

Selçuk Eşsiz - https://orcid.org/0000-0002-2850-4361

Emine Salamci - https://orcid.org/0000-0003-2828-6154

\section{References}

1. von Nussbaum, F.; Spiteller, P. $\beta$-Amino Acids in Nature. In Highlights in Bioorganic Chemistry: Methods and Applications; Schmuck, C.; Wennemers, H., Eds.; Wiley-VCH: Weinheim, Germany, 2004; pp 63-89. doi:10.1002/3527603727.ch1e

2. Juaristi, E.; Soloshonok, V. Enantioselective Synthesis of $\beta$-Amino Acids, 2nd ed.; John Wiley \& Sons: Hoboken, NJ, USA, 2005. doi:10.1002/0471698482

3. Risseeuw, M.; Overhand, M.; Fleet, G. W. J.; Simone, M. I. Amino Acids 2013, 45, 613-689. doi:10.1007/s00726-013-1521-1

4. Kiss, L.; Fülöp, F. Chem. Rev. 2014, 114, 1116-1169. doi:10.1021/cr300454h

5. Fülöp, F.; Martinek, T. A.; Tóth, G. K. Chem. Soc. Rev. 2006, 35, 323-334. doi:10.1039/b501173f

6. Norgren, A. S.; Büttner, F.; Prabpai, S.; Kongsaeree, P.; Arvidsson, P. I. J. Org. Chem. 2006, 71, 6814-6821. doi:10.1021/jo060854n

7. Cardillo, G.; Gentilucci, L.; Melchiorre, P.; Spampinato, S. Bioorg. Med. Chem. Lett. 2000, 10, 2755-2758. doi:10.1016/s0960-894x(00)00562-x

8. Kiss, L.; Mándity, I. M.; Fülöp, F. Amino Acids 2017, 49, 1441-1455. doi:10.1007/s00726-017-2439-9

9. Fülöp, F. Chem. Rev. 2001, 101, 2181-2204. doi:10.1021/cr000456z 10. Lee, M.-r.; Stahl, S. S.; Gellman, S. H. Org. Lett. 2008, 10, 5317-5319. doi:10.1021/ol802274x
11. Rasoanaivo, P.; Langlois, N.; Potier, P. Tetrahedron Lett. 1974, 15 , 3669-3672. doi:10.1016/s0040-4039(01)93205-8

12. Hashimoto, T.; Kondo, S.; Naganawa, H.; Takita, T.; Maeda, K.; Umezawa, H. J. Antibiot. 1974, 27, 86-87. doi:10.7164/antibiotics.27.86

13. Bunnage, M. E.; Ganesh, T.; Masesane, I. B.; Orton, D.; Steel, P. G. Org. Lett. 2003, 5, 239-242. doi:10.1021/ol0269704

14. Forró, E.; Fülöp, F. Org. Lett. 2003, 5, 1209-1212. doi:10.1021/ol034096o

15. Gardiner, J.; Anderson, K. H.; Downard, A.; Abell, A. D. J. Org. Chem. 2004, 69, 3375-3382. doi:10.1021/jo049794g

16. Fustero, S.; Bartolomé, A.; Sanz-Cervera, J. F.; Sánchez-Roselló, M.; Soler, J. G.; Ramírez de Arellano, C.; Fuentes, A. S. Org. Lett. 2003, 5 , 2523-2526. doi:10.1021/ol034827k

17. Palkó, M.; Benedek, G.; Forró, E.; Wéber, E.; Hänninen, M.; Sillanpää, R.; Fülöp, F. Tetrahedron: Asymmetry 2010, 21, 957-961. doi:10.1016/j.tetasy.2010.05.003

18. Forró, E.; Árva, J.; Fülöp, F. Tetrahedron: Asymmetry 2001, 12, 643-649. doi:10.1016/s0957-4166(01)00100-8

19. Salamci, E. Tetrahedron Lett. 2020, 61, 151728. doi:10.1016/j.tetlet.2020.151728

20. Karavaizoglu, U. N.; Salamci, E. New J. Chem. 2020, 44, 17976-17983. doi:10.1039/d0nj02697b

21. Zozik, Y.; Salamci, E.; Kilic, A. Tetrahedron Lett. 2017, 58, 4822-4826. doi:10.1016/j.tetlet.2017.11.014

22. Kaya, A. A.; Salamci, E.; Menzek, A.; Erdem, S. S.; Şahin, E.; Ecer, K. Tetrahedron 2017, 73, 5381-5388. doi:10.1016/j.tet.2017.07.040

23. Ecer, K.; Salamci, E. Tetrahedron 2014, 70, 8389-8396. doi:10.1016/j.tet.2014.08.060

24. Salamci, E. Tetrahedron 2010, 66, 4010-4015. doi:10.1016/j.tet.2010.04.052

25. Salamci, E.; Zozik, Y. Beilstein J. Org. Chem. 2021, 17, 705-710. doi:10.3762/bjoc. 17.59

26. Kardos, M.; Kiss, L.; Fülöp, F. Asian J. Org. Chem. 2015, 4, 1155-1159. doi:10.1002/ajoc.201500286

27. Das, B.; Thirupathi, P. J. Mol. Catal. A: Chem. 2007, 269, 12-16. doi:10.1016/j.molcata.2006.12.029

28. Crystallographic data for the structural analysis of compound $\mathbf{1 0}$ reported in this paper have been deposited with the Cambridge Crystallographic Data Centre as CCDC-2064456. These data are provided free of charge via the joint CCDC/FIZ Karlsruhe deposition service http://www.ccdc.cam.ac.uk/structures.

29. Gaussian 16, Revision C.01; Gaussian, Inc.: Wallingford, CT, 2019.

30. Becke, A. D. J. Chem. Phys. 1993, 98, 5648-5652. doi:10.1063/1.464913

31. Lee, C.; Yang, W.; Parr, R. G. Phys. Rev. B 1988, 37, 785-789. doi:10.1103/physrevb.37.785

32. Vosko, S. H.; Wilk, L.; Nusair, M. Can. J. Phys. 1980, 58, 1200-1211. doi:10.1139/p80-159

33. Stephens, P. J.; Devlin, F. J.; Chabalowski, C. F.; Frisch, M. J. J. Phys. Chem. 1994, 98, 11623-11627. doi:10.1021/j100096a001

34. Hariharan, P. C.; Pople, J. A. Theor. Chim. Acta 1973, 28, 213-222. doi:10.1007/bf00533485

35. McLean, A. D.; Chandler, G. S. J. Chem. Phys. 1980, 72, 5639-5648. doi:10.1063/1.438980

36. Krishnan, R.; Binkley, J. S.; Seeger, R.; Pople, J. A. J. Chem. Phys. 1980, 72, 650-654. doi:10.1063/1.438955

37. Marenich, A. V.; Cramer, C. J.; Truhlar, D. G. J. Phys. Chem. B 2009, 113, 6378-6396. doi:10.1021/jp810292n 


\section{License and Terms}

This is an open access article licensed under the terms of the Beilstein-Institut Open Access License Agreement (https://www.beilstein-journals.org/bjoc/terms), which is identical to the Creative Commons Attribution 4.0 International License

(https://creativecommons.org/licenses/by/4.0). The reuse of material under this license requires that the author(s), source and license are credited. Third-party material in this article could be subject to other licenses (typically indicated in the credit line), and in this case, users are required to obtain permission from the license holder to reuse the material.

The definitive version of this article is the electronic one which can be found at:

https://doi.org/10.3762/bjoc.18.7 